University of Nebraska - Lincoln

DigitalCommons@University of Nebraska - Lincoln

Agronomy \& Horticulture - Faculty Publications

Agronomy and Horticulture Department

$2-1983$

\title{
Combining Ability Effects for Forage Residue Traits in Grain Sorghum Hybrids
}

\author{
W. M. Ross \\ H. J. Gorz \\ University of Nebraska-Lincoln \\ Francis A. Haskins \\ University of Nebraska-Lincoln, fhaskins@neb.rr.com \\ G. H. Hookstra \\ J. K. Rutto
}

See next page for additional authors

Follow this and additional works at: https://digitalcommons.unl.edu/agronomyfacpub

Part of the Plant Sciences Commons

Ross, W. M.; Gorz, H. J.; Haskins, Francis A.; Hookstra, G. H.; Rutto, J. K.; and Ritter, R., "Combining Ability Effects for Forage Residue Traits in Grain Sorghum Hybrids" (1983). Agronomy \& Horticulture -- Faculty Publications. 284.

https://digitalcommons.unl.edu/agronomyfacpub/284

This Article is brought to you for free and open access by the Agronomy and Horticulture Department at DigitalCommons@University of Nebraska - Lincoln. It has been accepted for inclusion in Agronomy \& Horticulture -Faculty Publications by an authorized administrator of DigitalCommons@University of Nebraska - Lincoln. 


\section{Authors}

W. M. Ross, H. J. Gorz, Francis A. Haskins, G. H. Hookstra, J. K. Rutto, and R. Ritter 


\title{
Combining Ability Effects for Forage Residue Traits in Grain Sorghum Hybrids ${ }^{1}$
}

\author{
W. M. Ross, H. J. Gorz, F. A. Haskins, G. H. Hookstra, J. K. Rutto, and R. Ritter ${ }^{2}$
}

\begin{abstract}
Combining ability effects of 10 female and 10 male inbred lines were evaluated for agronomic, grain, and forage residue traits in $\mathbf{1 0 0}$ grain sorghum [Sorghum bicolor (L.) Moench] $F_{1}$ hybrids for 2 years. Traits studied were height, flowering, tillering, seed weight, yield, protein percentage, protein yield of grain, leaves, and stems; and in vitro dry matter disappearance (IVDMD) percentage and digestible dry matter (DDM) yield of leaves and stems. General combining ability (GCA) effects exceeded specific combining ability (SCA) effects for all traits except height in females and grain and leaf yields in males. Both GCA and SCA were low for tillering and stem protein percentage. Genetic ratios, resembling heritability, were higher for GCA than SCA except for height in females and tillering in males. Grain yield generally had no extremely strong negative phenotypic correlations with any forage residue trait although grain yield correlated with stem protein and stem IVDMD percentages produced negative values that would warrant monitoring in a breeding program. Grain yield, stem and leaf yields, and stem and leaf DDM yields all had moderate to strong positive relationships with each other. A few potentially useful parents were identified having high GCA effects for forage quality characters. Data on protein and IVDMD percentages of leaf and stem fractions from grain sorghum breeding nurseries and hybrid yield trials should be routinely collected.
\end{abstract}

Additional index words: Sorghum bicolor (L.) Moench, Yield, Protein, IVDMD, Livestock, Forage quality.

CRAIN sorghum [Sorghum bicolor (L.) Moench] is $G$ planted in the United States primarily for grain production, and hybrids normally are chosen for agronomic performance, pest resistance, or grain quality. Although substantial amounts of sorghum plant residues are utilized by livestock after the grain is harvested, little attention has been given to the crop's forage attributes by either the farmer or the plant breeder.

Combine-harvested grain sorghum fields traditionally have been pastured, but there is a trend toward removal of all residues from the field for use in beef or sheep wintering rations. High feed costs have encouraged increased use of sorghum residues, and improved mechanical technology has permitted baling, stacking, and ensiling of these materials as with conventional hay and forage crops. Obviously, not all residues from the grain sorghum crop are utilized because not all sorghum growers are livestock producers, and economics preclude hauling large amounts of bulky material great distances. Also, stubble often is purposely left in the field for moisture conservation and erosion control. Nonetheless, improvement in the feeding quality of that portion which is used as forage should directly benefit the livestock producer and, indirectly, the consumer.

Certain line cultivars, like 'Midland', were noted for their post-harvest pasture value; such types often had a juicy stalk and high stem sugar content (Swanson, 1951). However,

\footnotetext{
${ }^{1}$ Contribution from USDA-ARS and the Nebraska Agric. Exp. Stn Published as Paper No. 6837, Journal Series, Nebraska Agric. Exp. Stn. Received 1 Apr. 1982

${ }^{2}$ Geneticists, USDA-ARS; George Holmes professor, Dep. of Agronomy, Univ. of Nebraska, Lincoln, NE 68583; former graduate student now Dessert Seed Co., P.O. Box 181, El Centro, CA 92244; former graduate student, now Western Agric. Res. Stn., P.O. Box 169, Kakamega, Kenya; and former graduate student, now deceased.
}

studies that compare forage quality and forage yield of more than one grain sorghum hybrid in the same experiment are limited. In those few experiments, variability existed for leaf and stalk crude protein content, in vitro dry matter disappearance (IVDMD), and residue yield (Martin and Wedin, 1974; Ross et al., 1980; Rutto, 1978; Smith, 1977). The results suggest that improvement of forage traits in hybrid grain sorghum might be possible through plant breeding with short-term gains accomplished by crossing appropriate inbred lines and long-term gains through recurrent selection.

Numerous combining ability studies have been conducted with grain sorghum hybrids, beginning with Kambal and Webster (1965). Others are cited by Ritter (1978), and without exception, these reports dealt only with agronomic and grain traits. Only recently has the study of combining ability for forage traits been undertaken (Ross et al., 1980; Rutto, 1978). In these instances, general combining ability (GCA) was relatively high compared to specific combining ability (SCA) for leaf and stem protein, IVDMD, and forage yield in single-year tests, but correlations of forage traits with agronomic and grain traits were inconsistent. Our investigations supplement those of Rutto (1978) who studied GCA and SCA effects, genetic ratios, and correlations of forage, agronomic, and grain traits in a large number of $F_{1}$ hybrids.

\section{MATERIALS AND METHODS}

The experimental materials were 100 grain sorghum $F_{1}$ hybrids made by crossing 10 females with 10 males using a modified diallel described by Griffing (1956) based on the Method II mating system of Comstock and Robinson (1950). Both parental groups included standard and experimental inbred lines and represented a range of germplasm adapted to eastern Nebraska (Table 1).

The experiment was planted 26 May 1977 and 3 June 1978

Table 1. Parental lines used in combining ability study of grain sorghum hybrids.

\begin{aligned} & \hline Line Genotype \\ & \hline Female KS18 $\dagger \\ &$\hline 1 WD4 $\dagger \\ & 2$ N38 $\dagger \\ & 3$ CK60 $\times$ Kansas Sourless \\ & 4 B90 $\dagger \\ & 5$ Redlan $\dagger \\ & 6$ Wheatland $\dagger \\ & 7$ Martin $\dagger \\ & 8$ Combine Kafir-60 $\dagger \\ & 9 \\ & 10$ Tx414 $\dagger \\ &$ Male TAM Bulk 22 selection (SC 223) \\ & \hline 1 TAM Bulk 35 selection (SC 200) \\ & 2 Early Hegari $\times$ KS19 \\ & 3 KS19 $\times$ (Dwarf White Durra $\times$ Leoti-Atlas) \\ & 4 KS19 $\times$ (Club-Day $\times$ Neb. waxy) \\ & 5 KS21 $\times$ Tx414 \\ & 6 KS53 $\dagger \\ & 7$ WD16 $\dagger \\ & 8$ Tx2536 $\dagger \\ & 9 \\ & 10 \\ &$\hline\end{aligned}

$†$ Released inbred line. 
Table 2. GCA effects, significant GCA values, and experimental means of agronomic, grain, and forage residue traits of 100 grain sorghum hybrids grouped by female and male parents at Mead, Nebr., 1977-1978.

\begin{tabular}{|c|c|c|c|c|c|c|c|c|c|c|c|c|c|c|c|c|c|}
\hline \multirow{2}{*}{$\begin{array}{c}\text { Group } \\
\text { and } \\
\text { entry }\end{array}$} & \multirow{2}{*}{$\begin{array}{l}\text { Flower- } \\
\text { ing }\end{array}$} & \multirow[b]{2}{*}{ Height } & \multirow{2}{*}{$\begin{array}{c}\text { Seed } \\
\text { wt }\end{array}$} & \multirow{2}{*}{$\begin{array}{c}\text { Tiller- } \\
\text { ing }\end{array}$} & \multicolumn{3}{|c|}{ Yield } & \multicolumn{3}{|c|}{ Protein } & \multicolumn{3}{|c|}{ Protein yield } & \multicolumn{2}{|c|}{ IVDMD } & \multicolumn{2}{|c|}{ DDM yield } \\
\hline & & & & & Grain & Stem & Leaf & Grain & Stem & Leaf & Grain & Stem & Leaf & Stem & Leaf & Stem & Leaf \\
\hline & days & $\mathrm{cm}$ & $g / 100$ & $\begin{array}{l}\text { culms/ } \\
\text { plant }\end{array}$ & 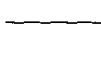 & $\mathrm{kg} / \mathrm{ha}$ & {$[-$} & $\ldots$ & $\%$ & 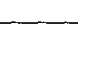 & $\ldots$ & $\mathrm{kg} / \mathrm{ha}$ & & $\%$ & & $-\mathrm{kg} /$ & \\
\hline \multicolumn{18}{|l|}{ Female } \\
\hline 1 & 1 & -1 & $0.14 \dagger$ & $0.1 \dagger$ & 51 & -198 & -52 & -0.3 & -0.6 & -0.2 & -8 & -24 & -11 & -1.4 & 0.7 & -109 & -10 \\
\hline 2 & $2 \dagger$ & -1 & 0.06 & 0 & -165 & -77 & $84 \dagger$ & -0.5 & -0.1 & $0.5 \dagger$ & -40 & -3 & $19 \dagger$ & 0.9 & $1.5 \dagger$ & -25 & $55 \dagger$ \\
\hline 3 & 1 & -4 & -0.18 & $0.1 \dagger$ & 169 & -143 & 51 & -0.2 & -0.2 & -0.4 & 17 & -12 & -1 & -1.0 & 0.5 & -85 & 33 \\
\hline 4 & $2 \dagger$ & 0 & -0.36 & 0 & -484 & $286 \dagger$ & $92 \dagger$ & $0.4 \dagger$ & 0.0 & $1.1 \dagger$ & -34 & $16 \dagger$ & $29 \dagger$ & $2.4 \dagger$ & $2.7 \dagger$ & $181 \dagger$ & $84 \dagger$ \\
\hline 5 & 0 & $4 \dagger$ & $0.15 \dagger$ & 0 & 169 & 175 & -1 & 0.0 & -0.1 & -0.3 & 11 & 5 & -5 & -0.5 & -1.4 & 70 & -22 \\
\hline 6 & -2 & 0 & -0.26 & 0 & $654 \dagger$ & -132 & 36 & -0.3 & 0.0 & -0.3 & $57 \dagger$ & -9 & -1 & 0.2 & -0.1 & -48 & 17 \\
\hline 7 & $2 \dagger$ & $5+$ & $0.10 \dagger$ & 0 & 217 & $337 \dagger$ & $113 \dagger$ & 0.1 & -0.1 & -0.2 & $35+$ & -12 & 11 & 0.1 & -1.0 & $157 \dagger$ & 31 \\
\hline 8 & 0 & -6 & $0.12 \dagger$ & 0 & -179 & -107 & 28 & 0.2 & $0.7 \dagger$ & 0.0 & -16 & $16 \dagger$ & 5 & -0.1 & -1.1 & -60 & -11 \\
\hline 9 & -3 & 3 & $0.13 \dagger$ & 0 & -342 & -34 & -139 & $0.7 \dagger$ & 0.3 & -0.2 & -5 & 3 & -20 & 0.0 & -1.2 & -12 & -79 \\
\hline 10 & -3 & 0 & $0.13 \dagger$ & 0 & -90 & -108 & -217 & 0.0 & 0.1 & 0.0 & -17 & -5 & -26 & -0.7 & -0.4 & -68 & -99 \\
\hline \multicolumn{18}{|l|}{ Sig. } \\
\hline value & 2 & 4 & 0.09 & 0.1 & 248 & 198 & 83 & 0.3 & 0.4 & 0.4 & 25 & 16 & 11 & 1.0 & 1.0 & 104 & 40 \\
\hline \multicolumn{18}{|l|}{ Male } \\
\hline 1 & -2 & -7 & -0.13 & 0 & -175 & -186 & -140 & 0.2 & 0.1 & -0.6 & -13 & -8 & -24 & 0.4 & -1.4 & -69 & -77 \\
\hline 2 & 0 & -4 & -0.25 & 0 & 195 & 108 & $81 \dagger$ & $0.4 \dagger$ & 0.2 & -1.2 & $48 \dagger$ & 12 & -9 & -1.8 & -0.8 & -13 & 21 \\
\hline 3 & $2 \dagger$ & 0 & -0.18 & 0 & 51 & $351+$ & $143+$ & 0.0 & 0.0 & -0.5 & 3 & $19 \dagger$ & 8 & 0.6 & 0.0 & $168 \dagger$ & $62 \dagger$ \\
\hline 4 & 0 & -1 & $0.24 \dagger$ & 0 & -152 & -3 & -94 & 0.1 & 0.0 & 0. & -10 & 2 & -6 & 0.5 & -0.9 & 11 & -57 \\
\hline 5 & $5+$ & $10^{+}$ & 0.04 & 0 & 315 & $318 t$ & $200 \dagger$ & -0.2 & -0.6 & $0.9 \dagger$ & 39 & 2 & $40+$ & -1.4 & $2.0 \dagger$ & $101 \dagger$ & $118 \dagger$ \\
\hline 6 & -1 & -5 & -0.11 & 0 & 29 & -130 & -102 & -0.7 & -0.4 & 0.3 & -36 & -14 & -9 & -2.6 & 0.9 & -114 & -30 \\
\hline 7 & -1 & 2 & 0.18 & 0 & 249 & 30 & 54 & 0.2 & 0.1 & 0.1 & 35 & 2 & 6 & 0.4 & -0.3 & 28 & 23 \\
\hline 8 & $2 \dagger$ & 0 & -.0 .17 & 0 & -197 & -252 & -53 & 0.0 & 0.0 & $0.7 \dagger$ & -16 & -10 & 5 & 1.2 & -0.2 & -82 & -30 \\
\hline 9 & -2 & -2 & 0.14 & 0 & -515 & -281 & -96 & $0.5 \dagger$ & $0.6 \uparrow$ & -0.3 & -38 & -1 & -15 & 1.0 & -0.3 & -100 & -49 \\
\hline 10 & -2 & $6 \dagger$ & $0.24 \dagger$ & 0 & 200 & 45 & 3 & -0.6 & -0.2 & 0.3 & -12 & -5 & 5 & $1.7 \dagger$ & 0.9 & 70 & 19 \\
\hline \multicolumn{18}{|l|}{ Sig. } \\
\hline value & 2 & 5 & 0.21 & 0.1 & 375 & 170 & 76 & 0.3 & 0.6 & 0.5 & 41 & 17 & 15 & 1.3 & 1.0 & 74 & 36 \\
\hline \multicolumn{18}{|l|}{ Exp. } \\
\hline meant & 70 & 105 & 2.40 & 1.1 & 5,298 & 2,525 & 1,484 & 11.6 & 4.6 & 11.7 & 587 & 108 & 170 & 44.6 & 44.3 & 1,149 & 673 \\
\hline
\end{tabular}

$\dagger$ Indicates significant GCA positive effects, $\geq$ significant values, by one-tailed $t$-tests. Effects in a column do not always sum to zero because of rounding.

$\ddagger$ Experimental mean plus GCA effect equals female mean averaged over males or male mean averaged over female as appropriate.

at the University of Nebraska Field Laboratory, Mead, on a Sharpsburg silty clay loam (Typic Argiudoll) to which $80 \mathrm{~kg} / \mathrm{ha}$ of $\mathrm{N}$ had been applied. One irrigation was given at the late booting stage in 1977 and none in 1978, which was more favorable for sorghum growth. Four replications of single-row plots $7.6 \mathrm{~m}$ long and $0.76 \mathrm{~m}$ apart were used each year. Conventional agronomic data (listed in Table 2) were collected with threshed grain yields taken from hand-harvested heads of $4.6 \mathrm{~m}$ of row having good plant stands averaging $15 \mathrm{~cm}$ between plants. Cleaned, threshed samples were used for 100 -seed weights and were ground for protein determinations by near-infrared reflectance analysis ( $\mathrm{Hy}-$ mowitz et al., 1974).

Soon after grain harvest, $3.0 \mathrm{~m}$ of row without heads in each plot were used for forage data. The plants were cut near ground level and stripped of their leaves with part of the sheaths remaining attached to the stems. Both the stem (including sheaths) and leaf components were weighed, and subsamples were taken from each to determine dry matter percentages. Dry matter yields were then calculated. Ground subsamples were analyzed for crude protein by the Kjeldahl method and for IVDMD analyses by the method of Tilley and Terry (1963). Digestible dry matter (DDM) yields were calculated by multiplying appropriate yield values by corresponding IVDMD percentages.

Analyses of variance (ANOVA) were performed, and tests of significance for hybrid entries, females, males, and females $X$ males for each trait were made by testing these mean squares with their respective year interaction mean squares.

Combining ability effects were determined for each trait as:

$$
\begin{aligned}
& \text { GCA (females) }=\bar{X}_{i}-\bar{Y}, \\
& \text { GCA (males) }=\bar{X}_{j}-\bar{Y}, \text { and } \\
& \text { SCA (hybrids) }=\bar{X}_{i j}-\bar{X}_{i}-\bar{X}_{j}+\bar{Y},
\end{aligned}
$$

where $\bar{X}_{i}$ is the mean of hybrids with a given female averaged over all replications, years, and males; $\overline{\mathrm{X}}_{\mathrm{j}}$ is the mean of hybrids with a given male averaged over replications, years, and females; $\overline{\mathrm{X}}_{\mathrm{ij}}$ is the mean of a given hybrid averaged over replications and years; and $\bar{Y}$ is the experimental mean.

Significance of GCA effects was tested as $\mathrm{t}=\mathrm{GCA} / \mathrm{SE}_{\mathrm{gca}}$ where the standard error (SE) is $\left(\mathrm{M}_{\mathrm{fy}} / \mathrm{rmy}\right)^{1 / 2}$ or $\left(\mathrm{M}_{\mathrm{my}} / \mathrm{rfy}\right)^{1 / 2}$ for females or males, respectively. $M_{f y}$ and $M_{m y}$ are the respective female $X$ year and male $X$ year mean squares, which are divided by the number of observations (replications, years, and males or females). Significance of SCA effects for hybrids was tested as $t=S C A$ / $\mathrm{SE}_{\mathrm{sca}}$ where $\mathrm{SE}$ is $\left(\mathrm{M}_{\mathrm{fmy}} / \mathrm{ry}\right)^{1 / 2}, \mathrm{M}_{\mathrm{fmy}}$ is the mean square for females $X$ males $X$ years, and ry is the number of observations. Onetailed t-tests were used for testing significance of GCA and SCA effects because interest was confined to positive values. calculated as $\theta_{\mathrm{f}}^{2} / \sigma_{\mathrm{p} f}^{2}, \theta_{\mathrm{m}}^{2} / \sigma_{\mathrm{p}_{\mathrm{m}}}^{2}$, and $\theta_{\mathrm{m}}^{2} / \sigma_{\mathrm{p}_{\mathrm{f}}}^{2}$ where $\theta_{\mathrm{f}}^{2}, \theta_{\mathrm{m}}^{2}$, and $\theta_{\mathrm{lm}}^{2}$ calculated as $\theta_{\mathrm{f}}^{2} / \sigma_{\mathrm{pf}}^{2}, \theta_{\mathrm{m}}^{2} / \sigma_{\mathrm{pm}}^{2}$, and $\theta_{\mathrm{m}}^{2} / \sigma_{\mathrm{pfm}}^{2}$ where $\theta_{\mathrm{l}}^{2}, \theta_{\mathrm{m}}^{2}$, and $\theta_{\mathrm{fm}}^{2}$ are the genetic components for females, males, and females $X$ males, respectively, and $\sigma_{\bar{p}}^{2}$ is their respective mean phenotypic variance. Although the genotypes in the experiment were fixed, this statistical treatment supplies useful breeding information.

Phenotypic correlations, with year and replication effects removed, were determined for $F_{1}$ hybrids, but only the correlations among forage traits and of forage traits with grain and agronomic traits are presented. Genetic correlations were not determined because of some extremely low, and sometimes negative, genetic component values which would give unrealistic or erroneous correlations. Although phenotypic correlations contain both genetic and environmental influences, they represent the associations actually observed.

\section{RESULTS AND DISCUSSION}

Computation of GCA effects identified at least one superior parent for all traits except grain yield and tillering 
Table 3. Genetic estimates of agronomic, grain, and forage residue traits in 100 grain sorghum hybrids.

\begin{tabular}{|c|c|c|c|c|c|c|c|c|c|}
\hline \multirow[b]{2}{*}{ Trait } & \multicolumn{6}{|c|}{ Genetic component $\dagger$} & \multicolumn{3}{|c|}{ Genetic ratio ${ }^{\dagger}$} \\
\hline & $\theta_{\mathrm{f}}^{2}$ & $\theta_{\mathrm{m}}^{2}$ & $\theta_{\mathrm{fm}}^{2}$ & $\sigma_{\mathrm{fy}}^{2}$ & $\sigma_{\mathrm{my}}^{2}$ & $\sigma_{\mathrm{fmy}}^{2}$ & $\theta_{\mathbf{f}}^{2} / \sigma_{\mathbf{p}_{f}}^{2}$ & $\theta_{\mathrm{m}}^{2} / \sigma_{\mathbf{p}_{\mathrm{m}}}^{2}$ & $\theta_{\mathrm{fm}^{2}}^{2} / \sigma_{\mathrm{p}_{\mathrm{fm}}^{2}}^{2}$ \\
\hline Flowering, days & $2.07 *$ & $3.14^{*}$ & $0.70^{*}$ & $2.67 *$ & 2.52 & $0.78^{*}$ & 0.60 & 0.71 & 0.45 \\
\hline Height, cm & 5.75 & $17.44^{*}$ & $8.39 *$ & $9.09 *$ & $16.81^{*}$ & $2.91^{*}$ & 0.54 & 0.67 & 0.63 \\
\hline Seed weight, $g / 100$ & $0.0337 *$ & $0.0229^{*}$ & $0.0050^{*}$ & $0.0046^{*}$ & $0.0253^{*}$ & $0.0053^{*}$ & 0.93 & 0.64 & 0.45 \\
\hline Tillering, culms/plant & $0.0023^{*}$ & $\ddagger$ & 0.0008 & 0.0003 & $0.0005^{*}$ & $\ddagger$ & 0.83 & 8 & 0.21 \\
\hline Grain yield, kg/ha & $87,594^{*}$ & 24,701 & 26,456 & $23,511 *$ & $70,936^{*}$ & $99,353^{*}$ & 0.83 & 0.37 & 0.19 \\
\hline Stem yield, kg/ha & $25,382^{*}$ & $39,425^{*}$ & $14,628^{*}$ & $18,935^{*}$ & $12,849^{*}$ & 1,958 & 0.68 & 0.82 & 0.39 \\
\hline Leaf yield, kg/ha & $9,294^{*}$ & $1,170^{*}$ & $8,135^{*}$ & $2,691^{*}$ & $\ddagger$ & 1,178 & 0.82 & 0.87 & 0.51 \\
\hline Grain protein, $\%$ & $0.0993^{*}$ & $0.1239^{*}$ & $0.0232 *$ & $0.0498^{*}$ & $0^{+} .0558^{*}$ & 0.0016 & 0.77 & 0.79 & 0.31 \\
\hline Stem protein, \% & 0.0691 & $\ddagger$ & $\ddagger$ & $0.0791^{*}$ & $0.2070^{*}$ & 0.0081 & 0.58 & $\S$ & $\S$ \\
\hline Leaf protein, \% & $0.1740^{*}$ & $0.3542^{*}$ & $\ddagger$ & $0.0582^{*}$ & $0.0986^{*}$ & $\ddagger$ & 0.81 & 0.85 & 8 \\
\hline Grain protein yield, $\mathrm{kg} / \mathrm{ha}$ & $752.98^{*}$ & 420.24 & 305.62 & $165.65^{*}$ & $848.55^{*}$ & $1,409.50^{*}$ & 0.82 & 0.46 & 0.16 \\
\hline Stem protein yield, $\mathrm{kg} / \mathrm{ha}$ & 93.82 & 18.38 & $\ddagger$ & $127.02^{*}$ & $143.40^{*}$ & 37.24 & 0.55 & 0.18 & $\S$ \\
\hline Leaf protein yield, $\mathrm{kg} / \mathrm{ha}$ & $246.74 *$ & $231.40^{*}$ & $98.50 *$ & $51.98^{*}$ & $120.33^{*}$ & 0.50 & 0.87 & 0.76 & 0.46 \\
\hline Stem IVDMD, \% & $0.8215^{*}$ & $1.4604^{*}$ & 0.0173 & $0.3819^{*}$ & $0.7988^{*}$ & $\ddagger$ & 0.72 & 0.73 & 0.01 \\
\hline Leaf IVDMD, \% & $1.5393^{*}$ & $0.7332^{*}$ & $0.2901^{*}$ & $0.3848^{*}$ & $0.3889 *$ & $\ddagger$ & 0.85 & 0.72 & 0.29 \\
\hline Stem DDM yield, kg/ha & $9,984 *$ & $7,133^{*}$ & 1,552 & $\ddagger$ & $2,133^{*}$ & 811 & 0.97 & 0.81 & 0.20 \\
\hline Leaf DDM yield, kg/ha & $2,733^{*}$ & $3,239 *$ & $1,366^{*}$ & $633^{*}$ & $432^{*}$ & 281 & 0.85 & 0.89 & 0.43 \\
\hline
\end{tabular}

* Indicates significant ( $\mathrm{P} \leq 0.10$ ) mean square value.

† The symbols $\sigma_{\mathrm{f}}^{2}, \theta_{\mathrm{m}}^{2}, \theta_{\mathrm{fm}}^{2}, \sigma_{\mathrm{fy}}^{2}, \sigma_{\mathrm{my}}^{2}$, and $\sigma_{\mathrm{fmy}}^{2}$ refer to the genetic components for females, males, and females $x$ males, and their year interactions, respectively; $\sigma_{\mathrm{p}}^{2}$ with subscript refers to the appropriate phenotypic variance.

$\ddagger$ Negative component interpreted as zero.

$\$$ Genetic ratio not calculated because of negative genetic component.

in males (Table 2). This was possible, despite nonsignificance sometimes found in the ANOVA for female or male traits, because the $t$-test measured only positive deviations from zero of all hybrids with a common parent and was only indirectly related to the separation of parental mean differences. Nonsignificant GCA yield effects for males were caused by high yield $X$ year interactions, but nonsignificant GCA tillering effects for males were caused by an apparent lack of variability in the germplasm. Although lack of variability of a trait obviously prevents breeding progress, the interaction of a trait with environments seriously hinders germplasm evaluation, even when variability exists.

A few promising parental lines were identified. Among the females, no. 6, an experimental line derived from a plant in a random-mating population from Uganda, was clearly superior for grain yield (Table 2). This parent was involved in five of the 10 highest yielding $F_{1}$ 's. Unfortunately, its A-line sheds pollen under stress and makes production of hybrids uncertain. Female 6 usually contributed about average GCA effects to forage residue traits. For such traits, GCA contributions of female 4 , a derivative of 'Kansas Sourless' forage sorghum, were noteworthy. Its GCA effects were high for stem and leaf yield, grain and leaf protein percentage, stem and leaf protein yield, stem and leaf IVDMD, and stem and leaf DDM yield; but it produced hybrids with low average grain yields. Female 3 (N38), an 'Ellis' derivative, had average GCA effects for grain yield and forage residue characters. Female 7 ('Redlan'), a kafir type, produced significant GCA effects for stem and leaf yield, grain protein yield, and stem IVDMD yield. Redlan is widely used in forage sorghum and sudangrass as well as in grain hybrids (Harvey, 1977). Our study substantiates the value of Redlan as a multipurpose female parent; it produced the second highest average yielding hybrids for grain and transmitted numerous favorable forage attributes.

Among males, no. 5, which has both forage sorghum and durra in its pedigree, had significant GCA effects for stem and leaf yield, leaf protein percentage, leaf protein yield, leaf IVDMD, and leaf and stem DDM yield. Its average grain yield was the highest, though not by a statistically significant margin, of all males. Male 5 produced the tallest and latest hybrids, and both traits were significant for GCA effects. Male 3 also produced hybrids with favorable forage traits. It gave significant GCA effects for stem and leaf yield, stem protein yield, and stem and leaf DDM yield. Male 3 is a selection from TAM Bulk 35 (SC 200), which is in the durra subseries (Scheuring and Miller, 1978). Durra appears to have contributed to the forage attributes of both males 3 and 5 .

The 100 hybrid combinations represented an array of genotypes with fairly wide ranges of values for most traits except tillering. Significant SCA effects were obtained for every trait as well as significant differences among trait means as determined by ANOVA. The highest mean values for a trait did not necessarily indicate significant SCA effects, or vice versa, because of the method of computing SCA effects. The large volume of data on 100 hybrids precludes the listing of means and SCA effects, but certain combinations will be discussed.

Hybrids possessing both improved grain and forage traits were sought not only for high SCA effects but for high absolute values. Because grain sorghum hybrids are grown primarily for grain purposes and secondarily for forage residues, the $F_{1}$ 's in this experiment that exceed the mean hybrid grain yield by at least one $\mathrm{SE}$, or those above 5,684 $\mathrm{kg} / \mathrm{ha}$, were determined. These 22 hybrids (female $X$ male) were $1 \times 1,1 \times 2,1 \times 7,1 \times 10,2 \times 2,2 \times 6,2 \times$ $10,3 \times 2,3 \times 7,5 \times 5,5 \times 10,6 \times 1,6 \times 3,6 \times$ $4,6 \times 5,6 \times 6,6 \times 8,6 \times 10,7 \times 3,7 \times 7,8 \times 5$, and $10 \times 3$. Only $3 \times 7$ had no less than average protein and IVDMD percentages and no less than average protein and DDM yields for stems and leaves. Female 3, a derivative of forage sorghum, and male 7 , an experimental line that is highly susceptible to the chinchbug, Blissus leucopterus leucopterus (Say), gave a hybrid with the second highest grain yield in the experiment in the absence of serious insect infestation.

From the genetic analyses (Table 3), GCA components tended to exceed SCA components in value for most traits. Exceptions were height in females and tillering, grain yield, and leaf yield in males. The low component value for height in females creates no practical breeding problems, but higher 
Table 4. Phenotypic correlations of forage traits with grain and agronomic traits and among forage traits in 100 grain sorghum hybrids.

\begin{tabular}{|c|c|c|c|c|c|c|c|c|c|c|}
\hline \multirow[b]{2}{*}{ Trait } & \multicolumn{2}{|c|}{ Yield } & \multicolumn{2}{|c|}{ Protein percent } & \multicolumn{2}{|c|}{ Protein yield } & \multicolumn{2}{|c|}{ IVDMD percent } & \multicolumn{2}{|c|}{ DDM yield } \\
\hline & Stem & Leaf & Stem & Leaf & Stem & Leaf & Stem & Leaf & Stem & Leaf \\
\hline Flowering, days & $0.44^{*}$ & $0.63 * \dagger$ & $-0.42^{*}$ & $0.40^{*}$ & 0.19 & $0.73 * \dagger$ & 0.01 & $0.45^{*}$ & $0.41 *$ & $0.67 * \dagger$ \\
\hline Height, cm & $0.53 * \dagger$ & $0.35^{*}$ & $-0.37 *$ & $0.29 *$ & 0.14 & $0.44 *$ & 0.05 & 0.13 & $0.54 * \dagger$ & $0.36^{*}$ \\
\hline Seed weight, g/100 & -0.04 & -0.18 & 0.02 & 0.08 & -0.08 & -0.12 & -0.01 & $-0.28^{*}$ & -0.02 & $-0.24^{*}$ \\
\hline Tillering, culms/plant & -0.15 & 0.01 & $-0.24 *$ & -0.05 & -0.27 * & -0.02 & -0.12 & 0.04 & -0.15 & 0.01 \\
\hline Grain yield, kg/ha & $0.30^{*}$ & $0.47^{*}$ & $-0.42^{*}$ & $-0.27 *$ & -0.08 & $0.27^{*}$ & $-0.35^{*}$ & -0.03 & $0.20^{*}$ & $0.41 *$ \\
\hline Grain protein, $\%$ & 0.09 & -0.17 & $0.56 * \dagger$ & $-0.21^{*}$ & $0.45^{*}$ & $-0.23^{*}$ & 0.17 & $-0.32^{*}$ & $0.20^{*}$ & $-0.25 *$ \\
\hline Grain protein yield, $\mathrm{kg} / \mathrm{ha}$ & $0.38^{*}$ & $0.46^{*}$ & $-0.21 *$ & $-0.30^{*}$ & 0.12 & $0.24^{*}$ & $-0.31^{*}$ & -0.15 & $0.27 *$ & $0.36^{*}$ \\
\hline Stem yield, kg/ha & - & $0.68 * \dagger$ & $-0.22 *$ & 0.08 & $0.70^{*}+$ & $0.61 * \dagger$ & 0.03 & 0.15 & $0.95 * \dagger$ & $0.64 * \dagger$ \\
\hline Leaf yield, kg/ha & & -. & $-0.24^{*}$ & 0.05 & $0.46^{*}$ & $0.87 * \dagger$ & 0.05 & $0.26^{*}$ & $0.65^{* \dagger}$ & $0.95 * \dagger$ \\
\hline Stem protein. \% & & & -. & $-0.20^{*}$ & $0.50 * \dagger$ & $-0.30^{*}$ & $0.33^{*}$ & $-0.32^{*}$ & -0.14 & $-0.32^{*}$ \\
\hline Leaf protein, \% & & & & - & -0.04 & $0.53^{*}+$ & $0.29 *$ & $0.60^{*} \dagger$ & 0.16 & $0.22^{*}$ \\
\hline Stem protein yield, $\mathrm{kg} / \mathrm{ha}$ & & & & & -- & $0.38^{*}$ & $0.25^{*}$ & -0.04 & $0.70 * \dagger$ & $0.37^{*}$ \\
\hline Leaf protein yield, $\mathrm{kg} / \mathrm{ha}$ & & & & & & -- & $0.20^{*}$ & $0.51 * \dagger$ & $0.62 * \dagger$ & $0.91 * \dagger$ \\
\hline Stem IVDMD, \% & & & & & & & -- & 0.11 & $0.33^{*}$ & 0.08 \\
\hline Leaf IVDMD, \% & & & & & & & & - & 0.16 & $0.52 * \dagger$ \\
\hline Stem DDM yield, kg/ha & & & & & & & & & -- & $0.62^{* \dagger} \dagger$ \\
\hline
\end{tabular}

* Values $\leq-0.20$ or $\geq 0.20$ are statistically significant at the 0.05 probability level.

$\dagger$ Values $\leq-0.50$ or $\geq 0.50$ probably have biological significance.

values for grain yield and leaf yield in males would be desirable and possibly could be found by more extensive sampling of germplasm. Both males and females $X$ males had relatively low component values for stem protein percentage, but the value for females was somewhat higher.

The genetic ratios generally reflected the findings on GCA and SCA components except that values for grain yield and leaf yield for males were higher than for females $X$ males. The genetic ratios for tillering, stem protein, and stem protein yield for males were either nil or very low. On the whole, however, the genetic components and genetic ratios suggest that breeding progress should be possible for improving most traits, at least when they are considered individually.

Although it is desirable to increase protein and IVDMD percentages while improving, or at least maintaining, grain and forage yield traits, possible negative associations among traits in their inheritance could prevent accomplishment of the objective. The correlations in Table 4 present the relationships among traits in this experiment. In a general way, the taller and later genotypes tended to have lower stem protein percentage but higher leaf protein percentage with a more pronounced positive effect on leaf protein than on stem protein yield. IVDMD percentage was little affected by flowering or height, except for a moderate positive correlation between leaf IVDMD percentage and flowering. The positive correlations between flowering and height with stem and leaf DDM yield were more pronounced.

Grain yield, the most important agronomic trait, was positively correlated with stem and leaf yield and negatively correlated with stem and leaf protein percentages. The correlations of grain yield were stronger with leaf yield and stem protein than with stem yield and leaf protein. The negative correlation between grain yield and grain protein in sorghum is well known, and it is not surprising that a similar relationship holds with grain yield and protein percentage of the forage components. Grain yield was only moderately negatively correlated with stem IVDMD percentage and only moderately positively correlated with leaf DDM yield.

The strongest positive values were obtained when stem yield and leaf yield were correlated with stem and leaf protein yield and with stem and leaf DDM yield. This parallels the high positive correlation of grain yield and grain protein yield (Ross et al., 1981). The correlations involving stem and leaf yield with stem protein percentages were weakly negative and were nil with leaf protein percentages. The only other correlations of consequence were the positive correlations of stem and leaf protein yield with stem and DDM yield. The correlation of stem yield and leaf DDM was the weakest. Leaf DDM yield also had a positive correlation with stem IVDMD percentage and stem DDM yield.

On the whole, the correlations obtained in this study do not suggest any formidable barriers to simultaneous improvement of agronomic, grain, and forage traits. The $\mathrm{r}^{2}$ values, which have more plant breeding significance, reduce the correlation data to much lower values. Not one of the probable biologically significant correlations (those exceeding 0.50) was negative, which should be advantageous to the plant breeder. Genetic correlations among these traits in a more random set of germplasm, however, could alter the conclusions. Stronger negative correlations between grain yield and stem protein and IVDMD percentages would then pose problems. In such instances index-type selection would have to be practiced with the likely result of slowed improvement in all traits of interest.

If quality of forage residue traits is assumed to be more important than quantity, then six hybrids $(2 \times 10,3 \times$ $7,5 \times 10,6 \times 4,6 \times 8$, and $6 \times 10$ ) had above-average grain yield and at least average protein and IVDMD percentages for both stems and leaves. If protein yield and DDM yield of stems and leaves are more important, then 12 of the 22 hybrids were acceptable. Increased protein yield traits appear to have been more easily achieved than increased protein and IVDMD percentages in this set of hybrids.

An ideal hybrid having favorable agronomic and grain traits combined with highly favorable forage traits may be difficult to develop, but superior genotypes should evolve from intensive plant breeding. Females 4, 6, and 7 and males 3 and 5 should be considered as parents to cross with other breeding lines to create genetic combinations not achieved in this experiment. These five lines generally produced high GCA effects for forage residue traits, and some of their experimental hybrids may exhibit high SCA effects plus high absolute values for both grain and forage traits.

Grain sorghum breeding and testing programs might routinely evaluate lines and hybrids for forage residue traits. Leaf and stem yield determinations involve considerable 
work and expense, but sampling grain sorghum plots for leaf and stem protein and IVDMD percentages can be more readily done. Cattle and sheep producers ultimately would benefit from the culture of high yielding grain sorghum hybrids possessing improved forage residue characters.

\section{REFERENCES}

1. Comstock, R.E., and H.F. Robinson. 1950. Estimation of average dominance of genes. p. 494-516. In J.W. Gowen (ed.) Heterosis. Iowa State Univ. Press, Ames.

2. Griffing, B. 1956. A generalised treatment of the use of diallel crosses in quantitative inheritance. Heredity 10:31-50.

3. Harvey, P.H. 1977. Sorghum germplasm base in the United States. Proc. Annu. Corn and Sorghum Res. Conf. 32:186-198.

4. Hymowitz, T., J.W. Dudley, F.I. Collins, and C.M. Brown. 1974 Estimations of protein and oil concentrations in corn, soybean, and oat seed by near-infrared light reflectance. Crop Sci. 14:713-715.

5. Kambal, A.E., and O.J. Webster. 1965. Estimates of general and specific combining ability in grain sorghum, Sorghum vulgare Pers. Crop Sci. 5:521-523.

6. Martin, N.P., and W.F. Wedin. 1974. Effect of fall weathering on yield and composition of grain sorghum stover. Agron. J. 66:669-672.
7. Ritter, R. 1978. Combining ability for agronomic traits in $F_{1}$ grain sorghum hybrids. Ph.D. Diss. Publication order no. 7906230 . Univ. of Nebraska. Univ. Microfilms. Ann Arbor, Mich. (Diss. Abstr. Int. 39:4138B. 1979).

8. Ross, W.M., H.J. Gorz, and F.A. Haskins. 1980. A preliminary investigation of forage quality characters in hybrid grain sorghum residues. Maydica 25:41-53.

9. ---, K.D. Kofoid, J.W. Maranville, and R.L. Voigt. 1981. Selecting for grain protein and yield in sorghum random-mating populations. Crop Sci. 21:774-777.

10. Rutto, J.K. 1978. Evaluation of grain sorghum hybrids and parental lines for residue yield and quality. M.S. Thesis. Univ. of Nebraska.

11. Schuering, J.F., and F.R. Miller. 1978. Fertility restorers and sterility maintainers to the milo-kafir genetic cytoplasmic male sterility system in the sorghum world collection. Texas Agric. Exp. Stn. MP-1367.

12. Smith, D.H. 1977. Effect of physiologic and management factors on yield and quality of grain sorghum [Sorghum bicolor (L.) Moench] residues. Ph.D. Diss. Publication order no. 7732137. Univ. of Nebraska. Univ. Microfilms. Ann Arbor, Mich. (Diss. Abstr. Int. 38:3502B. 1978)

13. Swanson, A.F. 1951. Grain and forage sorghum for Kansas. Kansas Agric. Exp. Stn. Bull. 349

14. Tilley, J.M., and R.A. Terry. 1963. A two-stage technique for in vitro digestion of forage crops. J. Brit. Grassl. Soc. 18:104-108. 